\title{
Effect of compaction pressure on consolidation behaviour of unsaturated silty soil
}

\author{
A.R. Estabragh, A.A. Javadi, and J.C. Boot
}

\begin{abstract}
The effect of compaction pressure on subsequent soil behaviour during isotropic consolidation has been investigated by conducting controlled-suction triaxial tests on samples of an unsaturated compacted silty soil. A comprehensive set of laboratory experiments was carried out in a double-walled triaxial apparatus on samples of unsaturated soil that were prepared using two different compaction pressures. The axis translation technique was used for creating the desired suctions in the samples. In the experiments, the soil samples were subjected to isotropic consolidation under constant suctions. The results show that different compaction pressures produce different fabrics in a soil and therefore affect the behaviour of the soil. The results also show that the value of yield stress and the location of the loading-collapse (LC) yield curve are functions of soil fabric. Furthermore, it is shown that the slopes of normal consolidation lines for densely and loosely compacted samples differ in unsaturated conditions but are the same in saturated soils. A comparison is made between the behaviour of the dense and loose samples, and the difference in the behaviour is explained.
\end{abstract}

Key words: suction, unsaturated soil, compaction, consolidation, soil fabric.

Résumé : On a étudié l'effet de la pression de compactage sur le comportement subséquent du sol durant une consolidation isotrope au moyen d'essais triaxiaux à succion contrôlée sur des échantillons d'un sol limoneux non saturé compacté. On a réalisé un vaste ensemble d'expériences en laboratoire dans un appareil triaxial à double paroi sur des échantillons de sol non saturé qui ont été préparés en utilisant deux différentes pressions de compactage. La technique de translation d'axe a été utilisée pour créer les succions désirées dans les échantillons. Dans les expériences, les échantillons de sol ont été soumis à une consolidation isotrope sous des succions constantes. Les résultats montrent que des pressions différentes de compactage produisent différentes fabriques dans un sol, et en conséquence, influence le comportement du sol. Les résultats montrent également que la valeur de la limite élastique et la localisation de la courbe limite d'effondrement (LC) sont fonction de la fabrique du sol. De plus, on montre que les pentes des lignes de consolidation normale pour les échantillons compactés dans des états denses ou meubles (qui seront appelés ici denses et meubles respectivement) diffèrent dans les conditions non saturées, mais elles sont les mêmes dans les sols saturés. On a fait une comparaison entre le comportement des échantillons denses et meubles, et la différence de comportement a été expliquée.

Mots clés : succion, sol non saturé, compactage, consolidation, fabrique du sol.

[Traduit par la Rédaction]

\section{Introduction}

Compacted soils are commonly used in the construction of several soil structures. The behaviour of compacted unsaturated soil is not fully understood because of its unsaturated state. An understanding of the mechanical behaviour of these unsaturated soils is therefore vital for the effective design and analysis of many foundations, slopes, embankments, and retaining structures. There are relatively few experimental data on the mechanical behaviour of compacted unsaturated soils, and therefore more information is needed in this respect for a better understanding of compacted un-

Received 19 April 2002. Accepted 8 December 2003. Published on the NRC Research Press Web site at http://cgj.nrc.ca on 2 July 2004.

A.R. Estabragh ${ }^{1}$ and A.A. Javadi. Department of Engineering, School of Engineering, Computer Science and Mathematics, University of Exeter, Exeter EX4 4QF, Devon, UK.

J.C. Boot. Department of Civil and Environmental Engineering, University of Bradford, Bradford, West Yorkshire, BD7 1DP, UK.

${ }^{1}$ Corresponding author (e-mail: A.R.Estabragh@exeter.ac.uk). 
saturated soils and their behaviour. Over the past 10 years a significant amount of research has been aimed at understanding the behaviour of unsaturated soils. It is generally accepted that the mechanical behaviour of unsaturated soils does not obey the principle of effective stress (Jennings and Burland 1962; Wheeler and Karube 1995) and requires the use of two independent stress state variables. In the threedimensional case, four stress parameters are required to explain the stress state at any point within an unsaturated soil. For axisymmetric conditions the number of stress parameters reduces to a total of three, which are usually chosen as mean net stress $\left(p^{\prime}\right)$, deviator stress $(q)$, and suction $(s)$ and defined as

$$
p^{\prime}=\frac{\sigma_{1}+2 \sigma_{3}}{3}-u_{\mathrm{a}}
$$

$$
\begin{aligned}
& q=\sigma_{1}-\sigma_{3} \\
& s=u_{\mathrm{a}}-u_{\mathrm{w}}
\end{aligned}
$$

where $\sigma_{1}$ and $\sigma_{3}$ are the axial and radial total stresses, respectively; and $u_{\mathrm{a}}$ and $u_{\mathrm{w}}$ are the pore-air and pore-water pressures, respectively.

The fabric or structure of a soil consists of different particles that join together to form the mass of the soil. The fabric of compacted soils is generally explained in terms of the compaction conditions and can therefore be estimated by specifying a few control variables, namely compaction water content with regard to the optimum, energy of compaction (or attained density), and compaction method. It is generally accepted that the role of fabric in the behaviour of soils is more important for unsaturated soil than for saturated soil (Alonso et al. 1987). In unsaturated soils the fabric controls the conditions of water, especially its suction potential. In fact, mineralogical composition affects the adsorption component of matric suction, and the internal geometry controls the capillary component (Alonso et al. 1987). The knowledge of the fabric of unsaturated soils plays an important role as an aid to understanding its mechanical response and to facilitating qualitative predictions of different environmental factors such as the effect of changes in pore-water chemistry. Gens (1995) explained some aspects of the compaction procedure, such as the compaction water content and compaction pressure, which have a significant influence on the subsequent mechanical behaviour of compacted finegrained soils. The influence of compaction procedure on subsequent mechanical behaviour is commonly attributed to the different forms of soil fabric that are produced when the compaction procedure is varied (Seed and Chan 1959; Barden and Sides 1970). Although the advent of direct observational methods such as the scanning electron microscope or porosimeters has modified significantly the accepted ideas on compacted soil fabric, behaviour differences are still generally attributed to different initial soil fabrics set up by the compaction process. It is often implied that these changes in soil fabric are of such fundamental importance to the subsequent soil behaviour that different compaction procedures effectively produce entirely different soils. This would mean that some or all of the soil constants in an elastoplastic model would take different values depending on the compaction procedure (Sivakumar and Wheeler
2000). Many authors have reported on the basis of microscopy that substantial differences in the fabric of compacted fine-grained soil can result from change in compaction water content. Delage et al. (1996) suggested that there are two levels of soil fabric (microfabric and macrofabric) for silty soils when compacted dry of optimum. They indicated that the most important differences occur in the macrofabric. There is a question of whether the influence of compaction procedure can be explained entirely on the basis of the initial state of the soil or different compaction procedures effectively lead to different soils. Alonso et al. (1992) originally argued, on the basis of experimental data reported by Lawton et al. (1989, 1991), that the influence of compaction procedure could be explained entirely in terms of the effect on initial state. Subsequent work suggested, however, that the value of specific volume (v) achieved during compaction also affects soil model parameters such as slope of the normal consolidation line $(\lambda(s))$ and elastic swelling index $(k)$ (Alonso et al. 1995). Gens (1995) indicated that any effects of the compaction procedure on the mechanical behaviour which cannot be explained by variation in the initial soil state are presumably attributable to difference in soil fabric.

\subsection{Consolidation}

The application of load to an unsaturated soil sample will result in the generation of excess pore-air and pore-water pressures. The excess pore pressures will dissipate with time and will eventually return to their original values before loading. The dissipation process of pore pressure is called consolidation and results in a volume decrease or settlement (Fredlund and Rahardjo 1993). In saturated soils, the instantaneously applied total stress is first supported by the pore water and the soil skeleton is progressively loaded during pore-pressure dissipation.

Barden and Sides (1970) developed a modified Rowe cell to conduct controlled-suction one-dimensional consolidation tests on unsaturated compacted soils. The suction was controlled or measured using the axis translation technique. Subsequently, this type of apparatus was successfully used by many other researchers such as Fredlund and Morgenstern (1977) and Escario and Juca (1989).

In oedometer testing, the soil sample is laterally confined and therefore any movement of the sample takes place vertically, making it easier to measure volume change of an unsaturated sample than in a triaxial apparatus. However, the consolidation characteristics of an unsaturated soil are best obtained from triaxial tests, which can give the initial pore pressures and the volume change under undrained conditions (Smith and Smith 1998). Sivakumar (1993), Zakaria (1994), and Cui and Delage (1996) conducted isotropic consolidation tests on unsaturated soil samples in a triaxial cell. In consolidation tests, each soil sample was compressed isotropically to a virgin state by increasing the mean net stress $\left(p^{\prime}\right)$ while holding the suction $(s)$ constant. The mean net stress $\left(p^{\prime}\right)$ is usually increased by increasing the cell pressure $\left(\sigma_{3}\right)$ while the suction is held constant by keeping the air and water pressures constant. Barden et al. (1969) examined the effect of the size of the stress increment ratio when adopting the method of step loading. They concluded that a high stress increment ratio always caused greater compression than when the same total increment of load was applied in a 
larger number of smaller increments. When an increment of external load is applied to a sample, excess pore-air and pore-water pressures will be generated within the sample. Any excess pore-air pressure that is generated will be dissipated very quickly due to the relatively high value of air permeability $\left(k_{\mathrm{a}}\right)$, and therefore the mean net stress $\left(p^{\prime}\right)$ rises almost immediately to its final value throughout the entire sample. The excess pore-water pressure, however, will take considerable time to dissipate to the water back pressure value because of the relatively low value of water permeability $\left(k_{\mathrm{w}}\right)$. This means that the suction increases in the sample gradually over the period of consolidation. Cui and Delage showed that a standard oedometer step-loading procedure is not suitable for unsaturated soils and should not be used for investigating compressibility properties under controlled suction. They concluded from the test results that for unsaturated soils this procedure overestimates the coefficient of compressibility $(\lambda(s))$ and underestimates the value of yield point and is invalid.

Sivakumar (1993) explained this behaviour of unsaturated soils during consolidation with the help of the yield locus proposed by Alonso et al. (1990). He investigated the movement of the yield curves for the top and bottom of a triaxial sample during the application of a step increment in cell pressure and during the subsequent consolidation period. At the bottom of the sample, the pore-water pressure dissipates quickly to the water back pressure and the soil reaches the final equilibrium on the related yield curve. At the top of the sample, the excess pore-water pressure occurs and, as it dissipates slowly during consolidation, the state of the soil at the top of the sample will be in the elastic region and away from the virgin state. The amount of excess pore-water pressure generated at the top of the sample could be minimized by applying the external load slowly to allow the excess pore-water pressure at the top of the sample to dissipate during loading. This could be done by ramping the cell pressure at a rate such that the excess pore-water pressure at the top of the sample is kept within acceptable limits. An additional advantage of using ramped consolidation is that it gives a continuous plot of specific volume $(v)$ versus mean net stress $\left(p^{\prime}\right)$ at a given suction. This plot can be used to identify the preconsolidation pressure $\left(p_{\mathrm{c}}^{\prime}\right)$ and the slope of the subsequent normal compression and unloading lines.

In this paper, the effects of compaction pressure on the consolidation behaviour of unsaturated soils are studied through a comprehensive set of experiments carried out on samples of a compacted silty soil. The samples were prepared by static compaction with two different compaction pressures. In what follows, the experimental procedure and results are presented and discussed. A comparison is made between the behaviour of dense and loose samples, and the difference in the behaviour is explained.

\section{Experimental study}

\subsection{Soil properties}

The soil used in the testing program was a silty soil with low plasticity. The soil comprised 5\% sand, $90 \%$ silt, and $5 \%$ clay and had a liquid limit of $29 \%$ and plasticity index of $19 \%$. The optimum water content in the standard compaction test was $14.5 \%$ and the maximum dry density was
$1.74 \mathrm{Mg} / \mathrm{m}^{3}$. According to the Unified Soil Classification System (USCS), the soil can be classified as silt with low plasticity (ML).

\subsection{Sample preparation}

The test program included a number of consolidation tests on samples of dense and loose soil. All of the samples (both dense and loose) were prepared by static compaction at the same water content but with two different compaction pressures. The samples were $38 \mathrm{~mm}$ in diameter and $76 \mathrm{~mm}$ high and were prepared at a water content of $10 \%(4.5 \%$ less than the optimum water content as determined by the standard compaction test). To adequately ensure uniform and repeatable density, preliminary static compaction tests were carried out by preparing samples in one, three, six, and nine layers in a compression frame. Compaction was carried out at a fixed displacement rate of $1.5 \mathrm{~mm} / \mathrm{min}$ to maximum vertical total stresses of 1600 and $400 \mathrm{kPa}$ for dense and loose samples, respectively. For each method of static compaction and sample preparation, the dry density was measured at a number of points along the length of the sample to help identify the optimum number of layers. Only the samples prepared by compaction in nine layers were found to produce excellent uniformity and repeatability of density. Consequently, this technique was used for sample preparation throughout the main test series.

\subsection{Experimental apparatus}

The tests were conducted in a double-walled triaxial cell. In the design of the apparatus, a Bishop and Wesley triaxial cell was modified to a double-walled cell and used for testing the unsaturated soil samples. A double-walled cell was used to avoid the difficulties that would otherwise have resulted from creep or hysteresis of the inner acrylic cell wall (Wheeler 1988). A schematic of the developed apparatus is shown in Fig. 1. Pore-water pressure $\left(u_{\mathrm{w}}\right)$ was applied and measured at the base of the sample through a saturated porous filter with an air-entry value of $500 \mathrm{kPa}$. Pore-air pressure $\left(u_{\mathrm{a}}\right)$ was applied at the top of the sample through a hydrophobic membrane and a filter with a low air-entry value (Javadi and Snee 2001). The free air could not pass through the high air-entry disk, but the diffused air could pass through it in solution with water, gather underneath the high air-entry disk, and form air bubbles. The accumulation of air bubbles under the high air-entry disk could prevent the passage of the water from the pore-water controller into the sample through the high air-entry disk and cause serious errors in the measurement of water volume change. To overcome this problem, a flushing system was designed and used, as suggested by Fredlund (1975). The axis translation technique, proposed by Hilf (1956), was used for creating the desired suctions in the samples. In this way, the values of $u_{\mathrm{w}}$ were maintained above atmospheric pressure. Four Geotechnical Digital Systems (GDS) pressure controllers were connected to the apparatus and controlled by a computer. The pressure controllers were used to apply and control the pressures in the inner and outer cells, the pore-water pressure, and the axial stress.

Sample volume change was measured by monitoring the flow of water into and out of the inner cell with a GDS controller unit. The measurements of sample volume change 
Fig. 1. Layout of the apparatus.

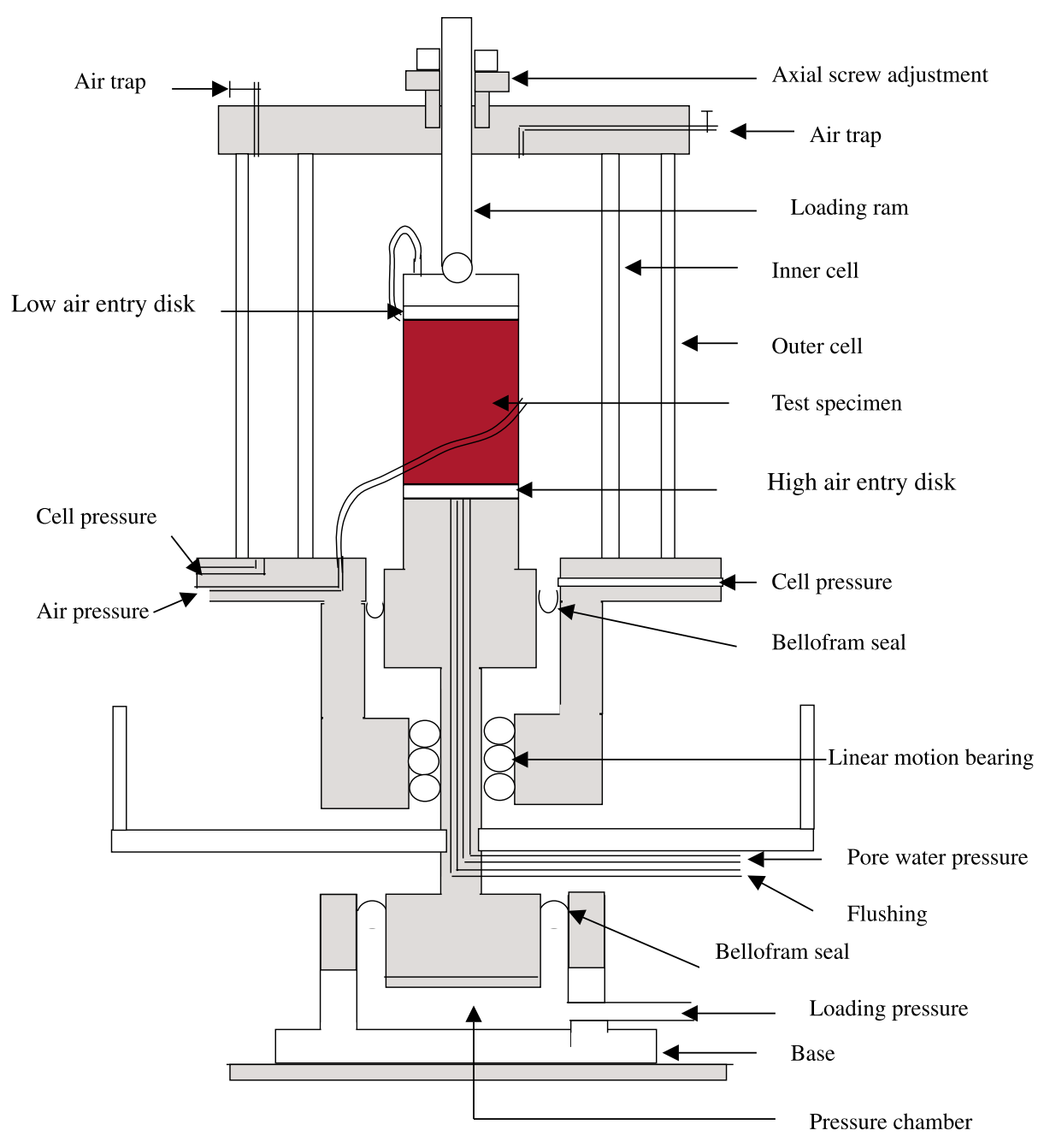

were used to monitor the variation in the specific volume (v). The flow of water to the sample was recorded by another GDS controller unit, and hence the variations in the water content $(w)$ and degree of saturation $\left(s_{\mathrm{r}}\right)$ were monitored. A conventional Bishop and Wesley hydraulic triaxial apparatus was used for conducting the tests on saturated samples. The control system for these tests consisted of three pressure controllers and a Digital Pressure Interface (DPI) unit. A computerized control system was used to log the data from all the GDS units and control a test to follow any required stress or strain path by adjusting the GDS controllers.

Before the main tests, calibration tests were carried out to estimate the volume change of different components of the system (including apparent volume change of the cell because of the effects of cell pressure, water absorption by the acrylic cell walls, loading ram displacement, and the drainage line) and to make the necessary corrections to the measurements.

\subsection{Experimental procedure}

\subsubsection{Equalization}

The purpose of the equalization tests was to create a desired suction in a sample by allowing the pore-air pressure and pore-water pressure to equalize to the applied air pressure and back pressure, respectively. During equalization, the suction in the sample changed gradually from its initially unknown value after compaction to the required value. After setting up the sample in the triaxial cell, all the tubes and fittings between the two cells and the spiral groove at the bottom of the high air-entry disk were flushed to prevent any air entrapment in the system that could affect the results. After flushing, the pressure of the two cells was increased simultaneously to $10 \mathrm{kPa}$ while the back pressure and air pressure were increased to 5 and $6 \mathrm{kPa}$, respectively. For achieving a desired matric suction in a sample, the target values of cell pressure, back pressure, and air pressure were selected. The target and initial values of inner cell pressure and back pressure together with the required time to reach the target values were set in the control program. The pressures were then ramped from the initial values to the target values at the rate of $1.6 \mathrm{kPa} / \mathrm{min}$ (rates of 1.6 and $2.0 \mathrm{kPa} / \mathrm{min}$ were previously used by Sivakumar (1993) and Zakaria (1994), respectively).

The consolidation control program was used at this stage of the test (equalization). The volumes of water inflow or outflow to the sample and to the inner cell were monitored during equalization. The equalization stage varied in length 
Table 1. Soil state parameters ( $w$, water content; $s_{\mathrm{r}}$, degree of saturation; $v$, specific volume) at the beginning and end of consolidation for dense samples.

\begin{tabular}{|c|c|c|c|c|c|c|c|}
\hline \multirow[b]{2}{*}{ Test No. } & \multirow[b]{2}{*}{$s(\mathrm{kPa})$} & \multicolumn{3}{|c|}{ Beginning of consolidation } & \multicolumn{3}{|c|}{ End of consolidation } \\
\hline & & $w(\%)$ & $s_{\mathrm{r}}(\%)$ & $v$ & $w(\%)$ & $s_{\mathrm{r}}(\%)$ & $v$ \\
\hline T3U1 & 300 & 10.05 & 37.70 & 1.73 & 9.59 & 44.36 & 1.59 \\
\hline T3U2 & 300 & 8.96 & 34.06 & 1.71 & 8.94 & 37.00 & 1.66 \\
\hline T3U3 & 300 & 10.30 & 37.25 & 1.75 & 10.16 & 39.08 & 1.71 \\
\hline T3U4 & 300 & 10.46 & 36.80 & 1.77 & 10.38 & 40.39 & 1.70 \\
\hline T3U5 & 300 & 10.34 & 37.80 & 1.74 & 10.17 & 40.92 & 1.68 \\
\hline T3U6 & 300 & 8.00 & 28.57 & 1.75 & 7.80 & 31.06 & 1.68 \\
\hline T3U7 & 300 & 10.07 & 36.96 & 1.74 & 10.07 & 41.00 & 1.67 \\
\hline T3U8 & 300 & 10.15 & 36.23 & 1.76 & 10.00 & 39.82 & 1.68 \\
\hline T3U9 & 300 & 9.44 & 33.62 & 1.76 & 9.40 & 37.43 & 1.68 \\
\hline T3U10 & 300 & 9.50 & 35.86 & 1.72 & 8.00 & 33.35 & 1.65 \\
\hline T2U1 & 200 & 10.15 & 37.15 & 1.74 & 10.20 & 46.31 & 1.60 \\
\hline $\mathrm{T} 2 \mathrm{U} 2$ & 200 & 10.85 & 40.49 & 1.73 & 10.07 & 42.00 & 1.65 \\
\hline T2U3 & 200 & 10.40 & 37.67 & 1.75 & 9.90 & 40.80 & 1.66 \\
\hline $\mathrm{T} 2 \mathrm{U} 4$ & 200 & 10.07 & 33.40 & 1.82 & 9.80 & 36.51 & 1.73 \\
\hline T2U5 & 200 & 10.70 & 37.65 & 1.77 & 10.81 & 42.61 & 1.69 \\
\hline T2U6 & 200 & 11.03 & 40.82 & 1.74 & 10.09 & 42.41 & 1.65 \\
\hline T2U7 & 200 & 10.71 & 38.68 & 1.75 & 10.67 & 43.44 & 1.67 \\
\hline T2U8 & 200 & 10.25 & 36.66 & 1.76 & 10.23 & 42.35 & 1.66 \\
\hline T1U1 & 100 & 15.81 & 60.22 & 1.71 & 16.03 & 71.80 & 1.61 \\
\hline T1U2 & 100 & 13.91 & 50.65 & 1.75 & 13.99 & 60.16 & 1.63 \\
\hline T1U3 & 100 & 14.84 & 52.08 & 1.77 & 15.02 & 63.13 & 1.65 \\
\hline T1U4 & 100 & 15.34 & 53.42 & 1.78 & 9.78 & 37.68 & 1.71 \\
\hline T1U5 & 100 & 13.06 & 47.07 & 1.76 & 13.36 & 56.10 & 1.65 \\
\hline T1U6 & 100 & 12.28 & 45.10 & 1.74 & 12.75 & 53.27 & 1.65 \\
\hline T1U7 & 100 & 12.06 & 45.30 & 1.72 & 10.22 & 43.84 & 1.64 \\
\hline T1U8 & 100 & 11.85 & 42.97 & 1.75 & 12.15 & 50.38 & 1.66 \\
\hline T1U9 & 100 & 12.74 & 47.37 & 1.73 & 13.03 & 56.43 & 1.63 \\
\hline T0U1 & 0 & 27.35 & 100.00 & 1.66 & 22.60 & 100.00 & 1.54 \\
\hline T0U2 & 0 & 31.23 & 100.00 & 1.66 & 22.50 & 100.00 & 1.52 \\
\hline T0U4 & 0 & 30.89 & 100.00 & 1.66 & 28.60 & 100.00 & 1.54 \\
\hline T0U5 & 0 & 30.24 & 100.00 & 1.66 & 27.60 & 100.00 & 1.57 \\
\hline T0U6 & 0 & 30.28 & 100.00 & 1.62 & 25.50 & 100.00 & 1.52 \\
\hline T0U7 & 0 & 31.38 & 100.00 & 1.59 & 26.57 & 100.00 & 1.44 \\
\hline T0U8 & 0 & 28.90 & 100.00 & 1.71 & 22.90 & 100.00 & 1.51 \\
\hline T0U9 & 0 & 30.90 & 100.00 & 1.62 & 28.30 & 100.00 & 1.55 \\
\hline T0U10 & 0 & 25.20 & 100.00 & 1.64 & 22.70 & 100.00 & 1.57 \\
\hline
\end{tabular}

between tests but usually took between 5 and 8 days. The equalization stage was terminated when the flow of water decreased to less than $0.1 \mathrm{~cm}^{3} /$ day (as used by Sivakumar 1993; Zakaria 1994; Sharma 1998).

\subsubsection{Consolidation stage}

After the sample was equalized at a specified suction ( 0 , $50,100,200$, or $300 \mathrm{kPa}$ ) and mean net stress, it was loaded isotropically under the constant suction (air back pressure and water back pressure were kept constant) to a preselected value of mean net stress (usually $550 \mathrm{kPa}$ ).

The process of ramped consolidation was used to limit the excess pore-water pressure generated at the top face of the sample. The target and initial values of cell pressure, back pressure, and the required time to achieve the target pressures were inserted in the control program. The required information during the ramp consolidation was recorded in a specified file. At the end of each stage the sample was left for $24 \mathrm{~h}$ under the target pressure to allow full dissipation of excess pore-water pressure. Each sample was consolidated to a virgin state.

\section{Results}

In the ramped consolidation stage the mean net stress $p^{\prime}$ was increased from 20 or $50 \mathrm{kPa}$ to $550 \mathrm{kPa}$ (the target value of $p^{\prime}$ ) while holding suction constant (at $0,50,100,200$, or $300 \mathrm{kPa}$ ). The experiments included equalization and ramped consolidation tests on 38 and 26 samples of dense and loose compacted soil, respectively. Tables 1 and 2 show the suction $(s)$, water content $(w)$, degree of saturation $\left(s_{\mathrm{r}}\right)$, and specific volume $(v)$ at the end of the consolidation and the corresponding values after equalization (beginning of consolidation) for dense and loose samples, respectively. The variations of specific volume (v) with mean net stress ( $p^{\prime}$, with $p^{\prime}$ on a logarithmic scale) during ramped consolida- 
Table 2. Soil state parameters ( $w$, water content; $s_{\mathrm{r}}$, degree of saturation; $v$, specific volume) at the beginning and end of consolidation for loose samples.

\begin{tabular}{|c|c|c|c|c|c|c|c|}
\hline \multirow[b]{2}{*}{ Test No. } & \multirow[b]{2}{*}{$s(\mathrm{kPa})$} & \multicolumn{3}{|c|}{ Beginning of consolidation } & \multicolumn{3}{|c|}{ End of consolidation } \\
\hline & & $w(\%)$ & $s_{\mathrm{r}}(\%)$ & $v$ & $w(\%)$ & $s_{\mathrm{r}}(\%)$ & $v$ \\
\hline P3U1 & 300 & 9.93 & 27.86 & 1.97 & 9.77 & 36.30 & 1.73 \\
\hline P3U2 & 300 & 12.99 & 37.61 & 1.94 & 13.13 & 47.00 & 1.76 \\
\hline P3U3 & 300 & 9.30 & 25.63 & 1.98 & 9.13 & 31.08 & 1.80 \\
\hline P3U4 & 300 & 9.97 & 27.00 & 1.97 & 9.86 & 36.29 & 1.74 \\
\hline P3U5 & 300 & 9.72 & 27.66 & 1.96 & 9.52 & 35.57 & 1.73 \\
\hline P3U6 & 300 & 9.70 & 26.87 & 1.98 & 9.61 & 32.92 & 1.79 \\
\hline P3U7 & 300 & 10.50 & 28.65 & 1.99 & 10.52 & 37.85 & 1.76 \\
\hline P3U8 & 300 & 9.20 & 25.40 & 1.98 & 10.52 & 37.75 & 1.76 \\
\hline P3U9 & 300 & 10.23 & 27.15 & 2.02 & 10.01 & 33.86 & 1.80 \\
\hline P2U1 & 200 & 10.95 & 30.75 & 1.97 & 11.14 & 39.81 & 1.76 \\
\hline P2U2 & 200 & 10.76 & 29.45 & 1.99 & 10.93 & 40.12 & 1.74 \\
\hline P2U3 & 200 & 10.84 & 29.00 & 2.02 & 10.97 & 39.57 & 1.75 \\
\hline P2U4 & 200 & 10.62 & 29.50 & 1.98 & 10.77 & 38.85 & 1.75 \\
\hline P2U5 & 200 & 10.40 & 28.50 & 1.99 & 10.52 & 37.75 & 1.76 \\
\hline P1U1 & 100 & 13.61 & 36.90 & 2.00 & 14.26 & 55.57 & 1.70 \\
\hline P1U2 & 100 & 13.57 & 40.00 & 1.92 & 14.05 & 60.27 & 1.63 \\
\hline P1U3 & 100 & 10.46 & 30.00 & 1.95 & 10.95 & 45.82 & 1.65 \\
\hline P1U4 & 100 & 13.27 & 36.44 & 1.99 & 13.80 & 54.24 & 1.69 \\
\hline P1U5 & 100 & 11.82 & 38.55 & 1.83 & 20.88 & 76.10 & 1.75 \\
\hline P0U1 & 0 & 27.12 & 91.70 & 1.80 & 22.65 & 90.22 & 1.68 \\
\hline P0U2 & 0 & 32.34 & 100.00 & 1.76 & 22.53 & 100.00 & 1.60 \\
\hline P0U3 & 0 & 27.97 & 94.84 & 1.80 & 22.64 & 94.00 & 1.66 \\
\hline P0U4 & 0 & 26.25 & 89.25 & 1.80 & 21.82 & 85.60 & 1.69 \\
\hline P0U5 & 0 & 17.76 & 69.00 & 1.70 & 18.29 & 90.00 & 1.55 \\
\hline P0U6 & 0 & 24.37 & 87.80 & 1.76 & 23.40 & 100.00 & 1.59 \\
\hline P0U7 & 0 & 33.28 & 100.00 & 1.76 & 27.44 & 100.00 & 1.60 \\
\hline
\end{tabular}

Fig. 2. Variation of specific volume during ramp consolidation for different suction values $(s)$ in dense samples.

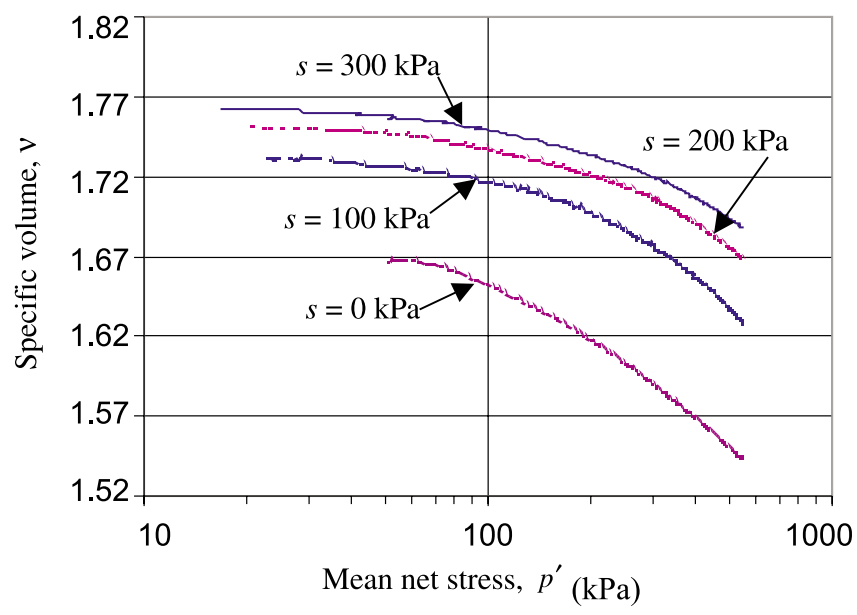

tion are shown for dense and loose samples in Figs. 2 and 3, respectively. It is shown from these figures that the volume of the soil decreased as the mean net stress increased. A continuous increase in mean net stress caused the soil to start to yield at some point. The values of yield stresses were estimated by the method of intersection of the two linear segments of the consolidation curve as proposed by Cui and Delage (1996) and Sharma (1998). As expected, the yield value increased with increasing suction. Figures 2 and 3
Fig. 3. Variation of specific volume during ramp consolidation for different suction values $(s)$ in loose samples.

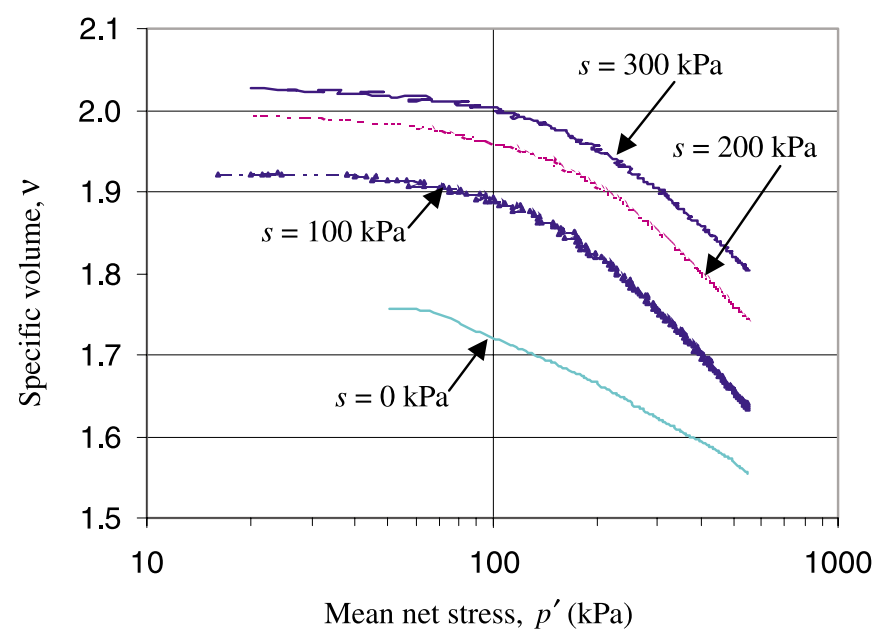

compare the behaviour of the dense and loose samples observed during the isotropic consolidation stage, for each value of suction. Inspection of these figures shows that, as expected, under the same constant suction, the values of yield stress for the dense samples are higher than the corresponding values for the loose samples. Tables 3 and 4 show the values of the mean net stress at yield $\left(p_{\mathrm{c}}^{\prime}\right)$ for the dense and loose samples, respectively. Further inspection of the 
Table 3. Values of $p_{\mathrm{c}}^{\prime}, \lambda(s)$, and $N(s)$ for dense samples during ramp consolidation.

\begin{tabular}{lllll}
\hline Test No. & $s(\mathrm{kPa})$ & $p_{\mathrm{c}}{ }^{\prime}(\mathrm{kPa})$ & $\lambda(s)$ & $N(s)$ \\
\hline T3U1 & 300 & 204 & 0.069 & 1.752 \\
T3U2 & 300 & 190 & 0.039 & 1.720 \\
T3U3 & 300 & 195 & 0.035 & 1.756 \\
T3U4 & 300 & 204 & 0.057 & 1.787 \\
T3U5 & 300 & 193 & 0.055 & 1.770 \\
T3U6 & 300 & 200 & 0.058 & 1.783 \\
T3U7 & 300 & 200 & 0.063 & 1.773 \\
T3U8 & 300 & 200 & 0.063 & 1.785 \\
T3U9 & 300 & 204 & 0.061 & 1.790 \\
T3U10 & 300 & 195 & 0.053 & 1.742 \\
T2U1 & 200 & 180 & 0.076 & 1.778 \\
T2U2 & 200 & 188 & 0.073 & 1.782 \\
T2U3 & 200 & 179 & 0.075 & 1.795 \\
T2U4 & 200 & 178 & 0.071 & 1.805 \\
T2U5 & 200 & 182 & 0.066 & 1.802 \\
T2U6 & 200 & 178 & 0.066 & 1.767 \\
T2U7 & 200 & 175 & 0.069 & 1.788 \\
T2U8 & 200 & 182 & 0.079 & 1.796 \\
T1U1 & 100 & 185 & 0.087 & 1.778 \\
T1U2 & 100 & 185 & 0.089 & 1.809 \\
T1U3 & 100 & 185 & 0.101 & 1.847 \\
T1U4 & 100 & 151 & 0.068 & 1.815 \\
T1U5 & 100 & 160 & 0.091 & 1.805 \\
T1U6 & 100 & 160 & 0.066 & 1.766 \\
T1U7 & 100 & 162 & 0.065 & 1.748 \\
T1U8 & 100 & 174 & 0.070 & 1.779 \\
T1U9 & 100 & 177 & 0.079 & 1.766 \\
T0U1 & 0 & 150 & 0.079 & 1.708 \\
T0U2 & 0 & 112 & 0.073 & 1.643 \\
T0U4 & 0 & 110 & 0.082 & 1.633 \\
T0U5 & 0 & 120 & 0.075 & 1.693 \\
T0U6 & 0 & 115 & 0.078 & 1.657 \\
T0U7 & 0 & 126 & 0.109 & 1.616 \\
T0U8 & 0 & 120 & 0.079 & 1.642 \\
T0U9 & 0 & 135 & 0.055 & 1.639 \\
T0U10 & 0 & 125 & 0.055 & 1.666 \\
\hline
\end{tabular}

ramped consolidation plots in Figs. 2 and 3 indicates that when the yield stress at a particular value of suction was exceeded, the soil states fell on an isotropic normal consolidation line (Fig. 4) defined by a linear relationship as used by Wheeler and Sivakumar (1995):

$$
\text { [4] } \quad v=N(s)-\lambda(s) \operatorname{Ln} \frac{p^{\prime}}{p_{\text {at }}}
$$

where $N(s)$ and $\lambda(s)$ are the intercept and slope of the normal consolidation line, respectively (see Fig. 5). The atmospheric pressure, $p_{\text {at }}$ (taken as $100 \mathrm{kPa}$ ), was included as a reference pressure in eq. [4] to make the expression dimensionally consistent and to minimize the error in the evaluation of $N(s)$. If the intercept $N(s)$ was evaluated at a reference pressure equal to $1 \mathrm{kPa}$, the value of $N(s)$ would be very susceptible to any small error in the slope $\lambda(s)$. Therefore the values of $N(s)$ were calculated where $p^{\prime}$ was $100 \mathrm{kPa}$. Tables 3 and 4 also show the values of $\lambda(s)$ and $N(s)$ corre-
Table 4. Values of $p_{\mathrm{c}}{ }^{\prime}, \lambda(s)$, and $N(s)$ for loose samples during ramp consolidation.

\begin{tabular}{lllll}
\hline Test No. & $s(\mathrm{kPa})$ & $p_{\mathrm{c}}{ }^{\prime}(\mathrm{kPa})$ & $\lambda(s)$ & $N(s)$ \\
\hline P3U1 & 300 & 180 & 0.189 & 2.056 \\
P3U2 & 300 & 182 & 0.151 & 2.017 \\
P3U3 & 300 & 180 & 0.155 & 2.065 \\
P3U4 & 300 & 182 & 0.203 & 2.086 \\
P3U5 & 300 & 182 & 0.181 & 2.037 \\
P3U6 & 300 & 186 & 0.154 & 2.059 \\
P3U7 & 300 & 179 & 0.176 & 2.058 \\
P3U8 & 300 & 179 & 0.173 & 2.061 \\
P3U9 & 300 & 179 & 0.165 & 2.086 \\
P2U1 & 200 & 158 & 0.162 & 2.038 \\
P2U2 & 200 & 148 & 0.181 & 2.052 \\
P2U3 & 200 & 146 & 0.183 & 2.067 \\
P2U4 & 200 & 151 & 0.172 & 2.048 \\
P2U5 & 200 & 158 & 0.176 & 2.065 \\
P1U1 & 100 & 118 & 0.196 & 2.036 \\
P1U2 & 100 & 120 & 0.199 & 1.976 \\
P1U3 & 100 & 113 & 0.218 & 2.026 \\
P1U4 & 100 & 111 & 0.198 & 2.031 \\
P1U5 & 100 & 120 & 0.177 & 2.051 \\
P0U1 & 0 & 73 & 0.063 & 1.790 \\
P0U2 & 0 & 66 & 0.076 & 1.731 \\
P0U3 & 0 & 68 & 0.075 & 1.786 \\
P0U4 & 0 & 75 & 0.061 & 1.798 \\
P0U5 & 0 & 76 & 0.109 & 1.744 \\
P0U6 & 0 & 70 & 0.067 & 1.706 \\
P0U7 & 0 & 64 & 0.063 & 1.709 \\
\hline
\end{tabular}

Fig. 4. Normal consolidation lines for dense and loose samples under various suctions $(s)$.

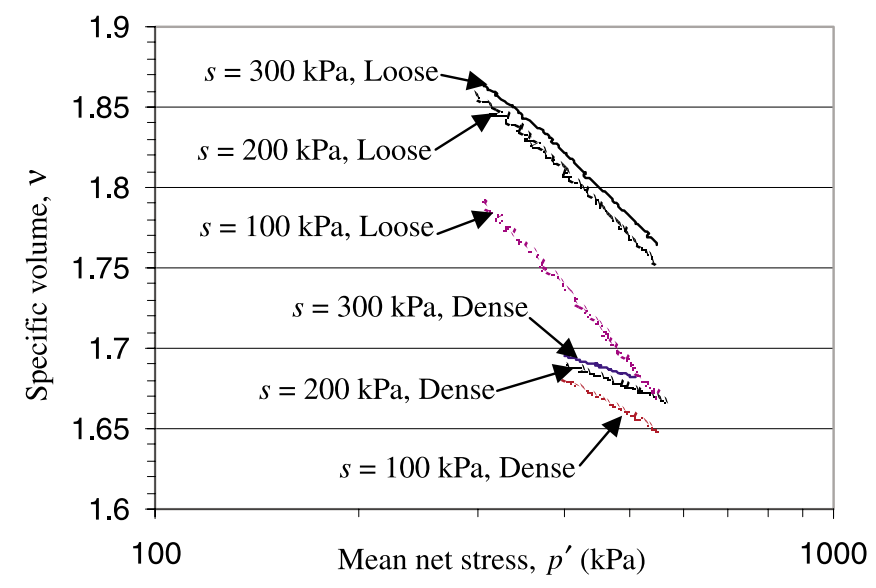

sponding to a reference mean net stress $\left(p_{\text {at }}=100 \mathrm{kPa}\right)$. Both $\lambda(s)$ and $N(s)$ were found to be functions of suction. The variation of $\lambda(s)$ with variations in suction for the dense and loose samples is shown in Figs. 6 and 7, respectively.

\section{Discussion}

For the isotropic stress state, the intersection of the yield surface with the $q=0$ (zero deviator stress) plane defines a loading-collapse (LC) yield curve (Alonso et al. 1987), with the isotropic yield stress increasing with increase in suction 
Fig. 5. Values of $N(s)$ and $\lambda(s)$ for the normal consolidation line.

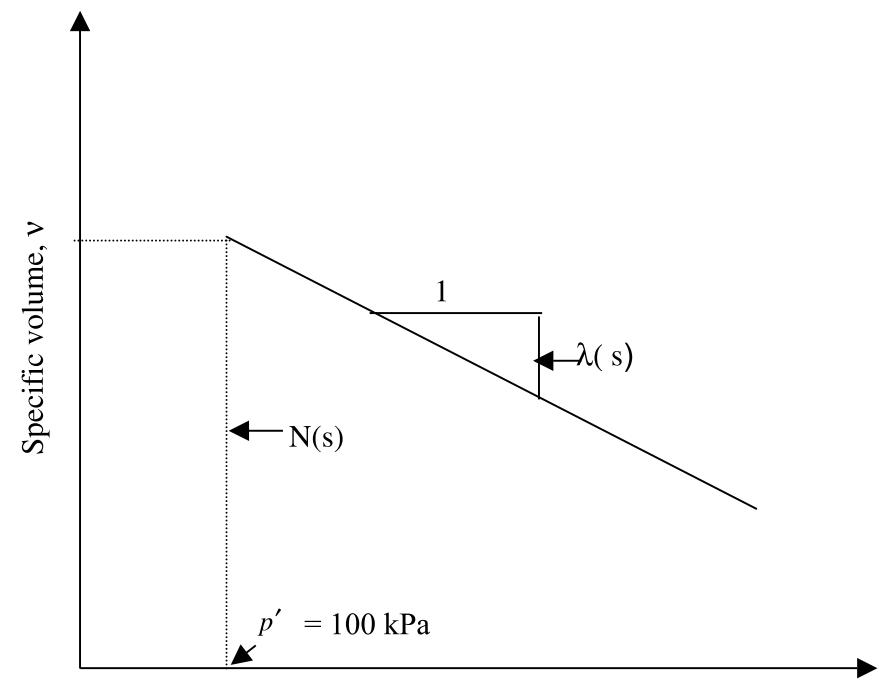

Mean net stress (logarithmic scale)

Fig. 6. Variation of $\lambda(s)$ with suction for dense samples.

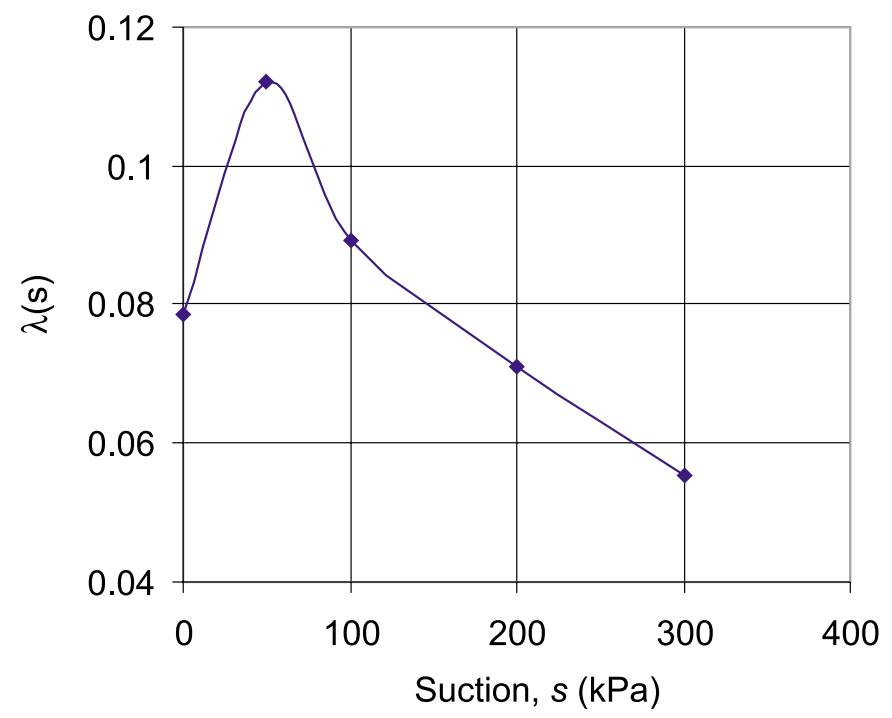

from the saturated value at zero suction. The stress states on the LC yield curve correspond to the virgin conditions, and the resulting values of specific volume lie on a unique isotropic normal compression surface in $v-p^{\prime}-s$ space. This corresponds to a series of normal compression lines for different values of suction in the $v-p^{\prime}$ plane, which can be expressed by eq. [4]. Wheeler and Sivakumar (1995) showed that the shape of the LC yield curve and the way this shape develops as the curve expands are uniquely defined by the variation in $N(s)$ and $\lambda(s)$ with suction and the values of the elastic parameters.

The LC yield curves for dense and loose samples were produced from the yield points obtained from the isotropic consolidation curves (Fig. 8). The shape of these LC yield curves is consistent with that proposed in the Alonso et al. (1990) model. The results show that the yield stresses at various suctions in dense samples are higher than those in the loose samples. It appears that the differences in the fabric of
Fig. 7. Variation of $\lambda(s)$ with suction for loose samples.

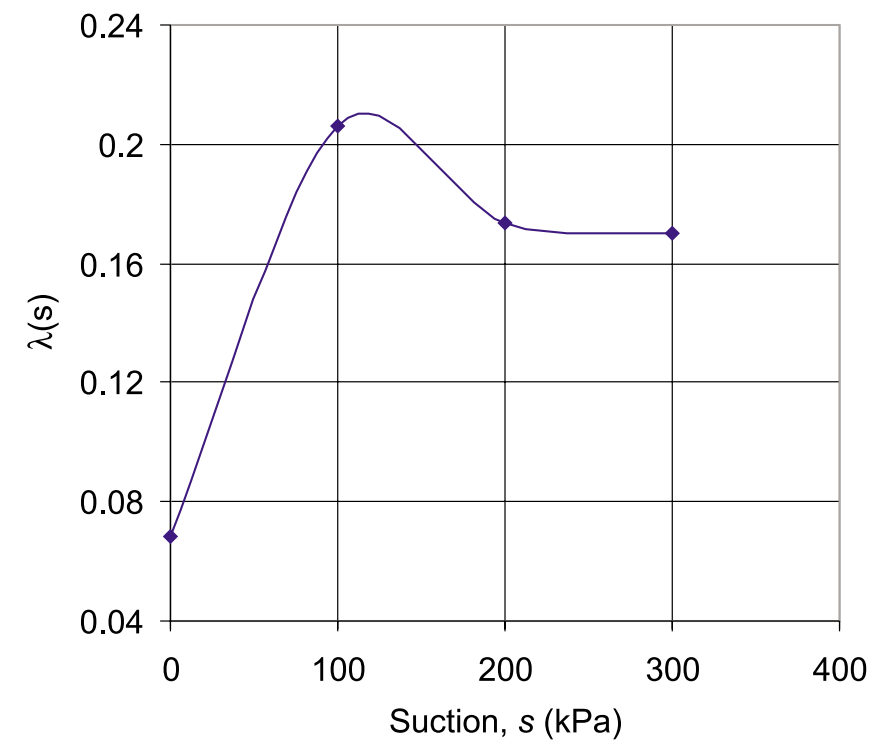

Fig. 8. Loading-collapse (LC) yield curve for dense and loose samples.

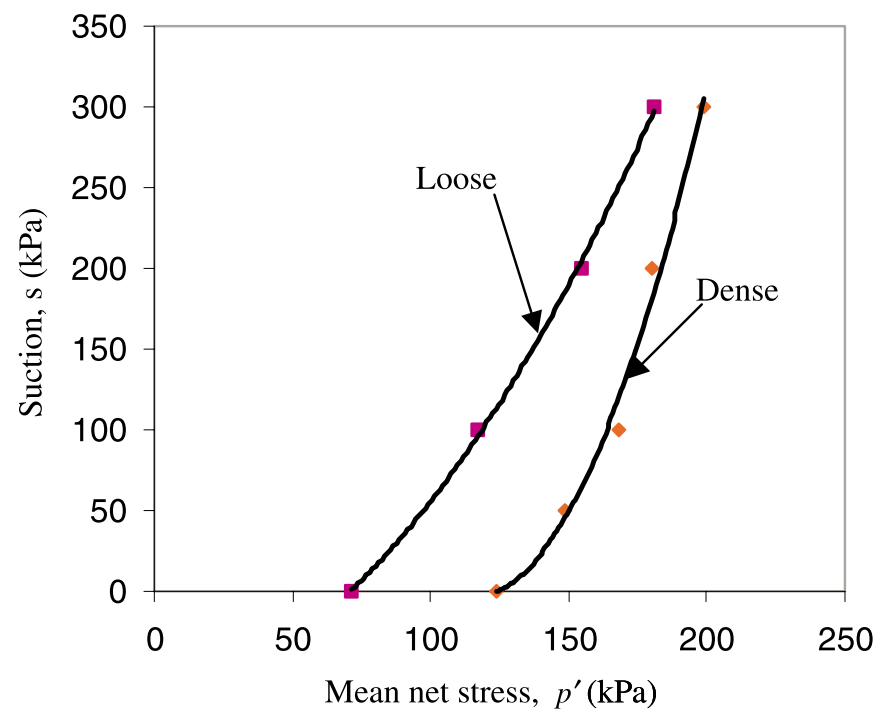

the dense and loose samples are reflected in the different LC yield curves. It can be observed that the location of the yield surface is closely related to the value of specific volume $(v)$ or dry density achieved by the compaction effort. It is presumed that the occurrence of plastic strains associated with expansion of the yield surface dominates the values of specific volume as suggested by Sivakumar and Wheeler (2000).

It was found from the experimental results that $\lambda(s)$ for dense (Fig. 6) and loose (Fig. 7) samples is a function of suction. The value of $\lambda(s)$ decreased with increasing suction for suctions greater than 80 and $100 \mathrm{kPa}$ for dense and loose samples, respectively. This behaviour was consistent with the model of Alonso et al. (1990). However, $\lambda(s)$ appeared to decrease sharply as the suction was reduced to zero. This behaviour was not consistent with the model of Alonso et al., who proposed that the slope of isotropic normal consolida- 
tion lines $\lambda(s)$ decreases monotonically with increasing suction from the saturated value $\lambda(0)$, becoming asymptotic to a value $r \lambda(0)$ at high suctions as

$$
\lambda(s)=\lambda(0)[(1-r) \exp (-\beta s)+r]
$$

where $r$ is a constant related to the maximum stiffness of the soil, $\beta$ is a parameter that controls the rate of increase of soil stiffness with suction, and $s$ is suction. It is possible that $\lambda(s)$ increased with decreasing suction right down to zero suction, and there was then a discontinuity in the value of $\lambda(s)$ corresponding to the change from unsaturated to saturated conditions. Therefore it can be concluded from the experimental results for both the dense and loose samples that the slope $\lambda(s)$ of the virgin line is suction dependent: the higher the suction, the smaller is the slope. The experimental results for both dense and loose samples show that the normal compression lines for different values of suction are straight lines and diverge with increasing mean net stress (Fig. 4). This divergence is more clear in the case of dense samples. This behaviour is more consistent with the model of Alonso et al., who predicted that the normal compression lines for different values of suction in the $v-p^{\prime}$ plane (with $p^{\prime}$ plotted on a logarithmic scale) are straight lines and the slope $\lambda(s)$ decrease monotonically with increasing suction. This finding is not consistent with the model of Wheeler and Sivakumar (1995), who suggested that normal compression lines converge with increasing mean net stress. It is shown in Fig. 4 that the normal compression lines for dense samples lie below the corresponding normal compression lines for loose samples. This difference in the location of the normal compression lines in dense and loose samples suggests that compaction with different compaction pressures affects some aspects of the soil behaviour.

The influence of an increase in compaction pressure on the fabric of samples compacted dry of Proctor optimum water content is probably limited to some compression of the large interpacket voids. The compression of large interpacket voids during increased compaction is similar to that occurring during virgin loading after compaction (Delage et al. 1996), and this should therefore be represented simply by additional expansion of the yield surface in the existing elastoplastic models.

Figure 9 shows the variation of the average value of $\lambda(s)$ for dense and loose samples under different values of suction. The value of $\lambda(s)$ for the loose samples is about 2.5 times greater than the value for the dense samples; however, in the saturated condition, their values are nearly the same. It is concluded that the higher the initial specific volume, the higher is the compressibility on the virgin line. This finding for saturated and unsaturated conditions seems to be compatible with the concept of the state surface proposed by Matyas and Radhakrishna (1968). When two samples are compacted with two different compaction pressures (1600 and $400 \mathrm{kPa}$ ), they reach two different final states of suction. Therefore, the samples with different suctions will be located at different places on the state surface. It is clear that the intersection of the state surface with the plane of zero suction is a curve. The projection of each point on the state surface is a point on the curve in the plane of zero suction. Therefore, when samples with different suctions (different compaction pressures) are soaked, they reach a unique satu-
Fig. 9. Variation of $\lambda(s)$ for dense and loose samples under various suctions.

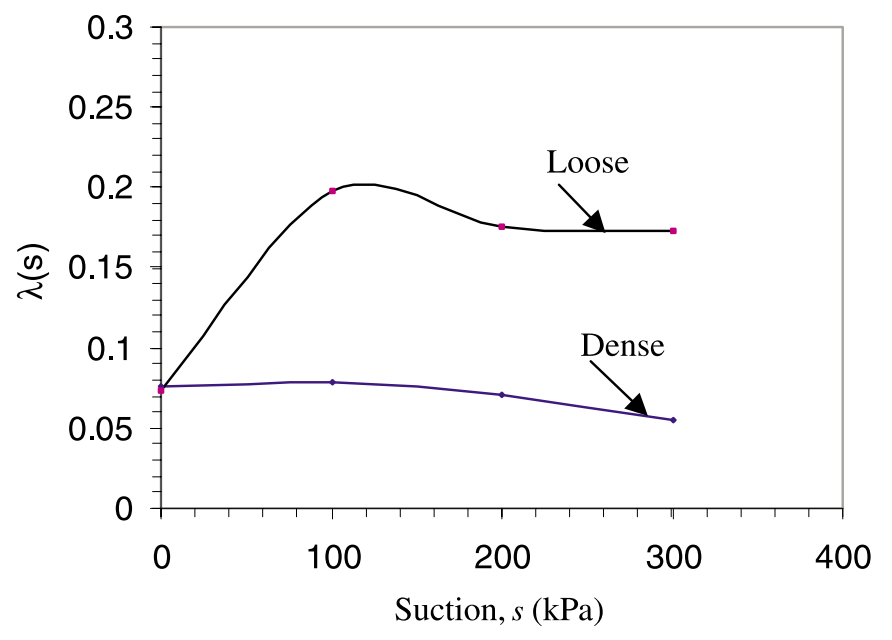

rated curve in the zero-suction plane, and consequently the value of $\lambda(s)$ for all samples is the same under saturated conditions.

It can also be concluded from the state surface proposed by Matyas and Radhakrishna (1968) that for unsaturated conditions, when two samples of a soil are compacted with the same water content but under two different compaction pressures, the denser sample will be less compressible than the loose sample.

The Alonso et al. (1990) model can also be used to explain this behaviour of unsaturated soils. In this model, the samples with the same suction follow the same path due to the variation of suction. Delage and Graham (1995) presented an interesting diagram (see Fig. 10) for a compacted loess. The curves in the diagram show the lines of equal suctions on the compaction curve. At low water contents, nearly vertical constant suction curves are observed, showing that density has no influence on the suction in this area. That is, compression of dry specimens occurs at constant suction. This is probably because compression is concentrated in air-filled parts of the soil while similar water-filled pores remain. The curves change progressively, however, as the water content increases and finally become asymptotic to the saturation hyperbola.

It can be concluded from the work of the aforementioned researchers that, on the dry side of compaction curve, the suction is nearly the same for different dry densities. Therefore, the loose and dense samples have nearly the same suction, as they have the same initial water content and are located on the dry side of compaction curve. When the suctions of these samples decrease due to soaking, they follow the same path in the LC yield curve. Therefore, in the saturated condition, the value of $\lambda(0)$ will be the same for these samples.

\section{Conclusion}

A series of controlled-suction consolidation tests on saturated and unsaturated samples of a compacted silty soil was used to investigate the influence of compaction pressure on subsequent soil behaviour. The primary influence of com- 
Fig. 10. Curves of equal suctions for a compacted loess (after Delage and Graham 1995).

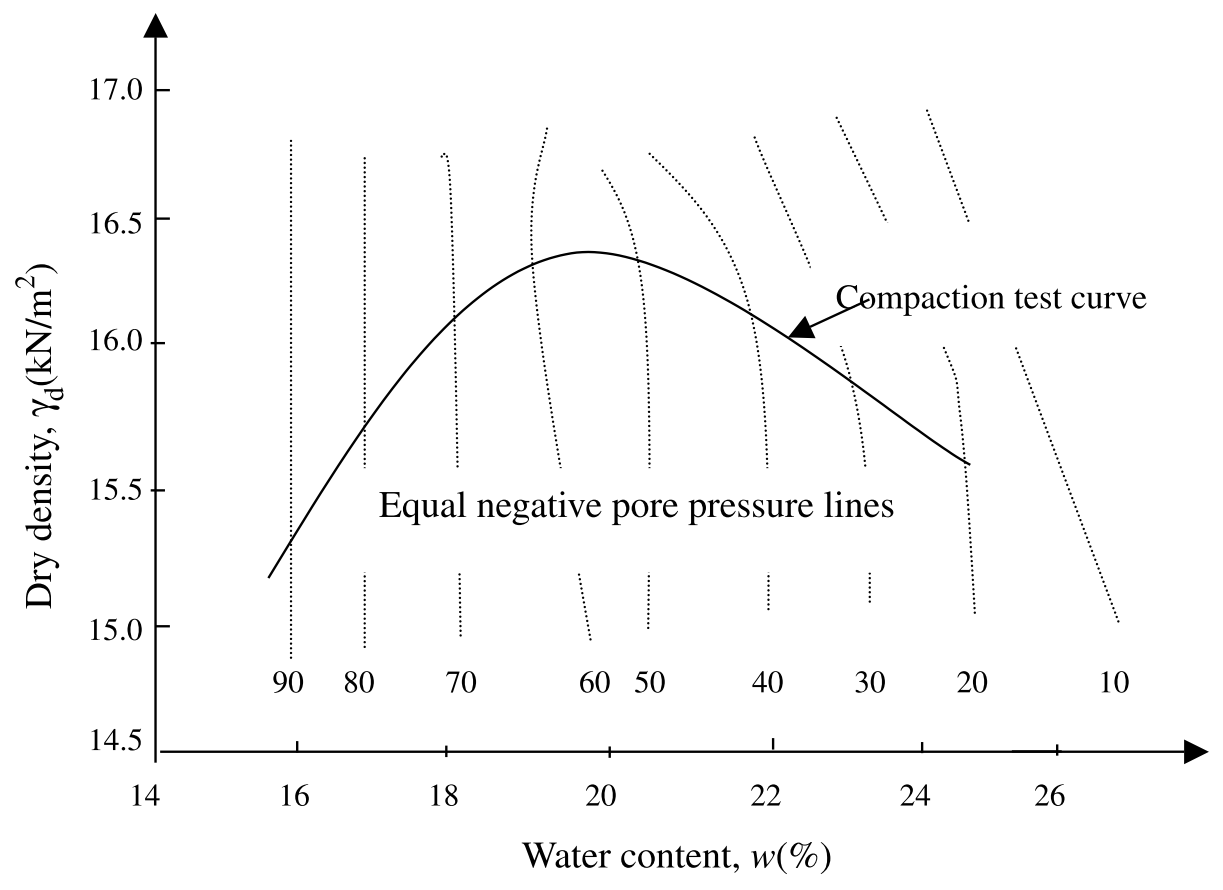

paction pressure was found to be on the initial state of samples through additional expansion of the yield curve during compaction to higher pressures. In addition, compaction pressure affects the positions of the normal compression lines for different values of suction, suggesting some influence of the initial compaction-induced soil fabric. From the results obtained it can be concluded that the greater compaction pressure used in the dense samples has resulted in additional expansion of the LC yield curve. It can be observed that as the dry density increases, the LC curves shift to the right, reflecting a lower value of void ratio. In contrast, the shape of the LC yield curves reflects initial fabric differences. It is concluded from Fig. 8 that, for dense and loose samples compacted to the same initial suction, the yield curve for the dense samples expanded to a much greater extent than the corresponding yield curve for the loose samples. The beneficial effects of increased compaction efforts are immediately apparent. A dense sample will yield at a higher stress during subsequent loading, and for a wide range of applied loading it is possible to eliminate the occurrence of wetting-induced collapse compression observed for loose samples.

The influence of the initial specific volume of loose and dense samples on the consolidation behaviour of unsaturated soils is different from that of saturated soils. For a given water content (in unsaturated soils), the compression index $(\lambda(s))$ decreases with increasing density. This is very important in the behaviour of unsaturated soils. This aspect of the unsaturated soil behaviour is not considered in the models proposed by Alonso et al. (1990) and Wheeler and Sivakumar (1995). Furthermore, the dry density achieved during compaction also affects the parameters of the models of Alonso et al. and Wheeler and Sivakumar. It appears, therefore, that variations in the initial fabric caused by compaction with different compaction pressures can result in differences that may require the materials to be modelled as different soils. It is often implied that these changes in soil fabric are of such fundamental importance to the subsequent soil behaviour that different compaction procedures could effectively produce different soils, so the relevant soil constants in any constitutive model will depend on the method of compaction.

\section{References}

Alonso, E.E., Gens, A., and Hight, D.W. 1987. Special problem soils. General report. In Proceedings of the 9th European Conference on Soil Mechanics and Foundation Engineering, Dublin, 31 Aug. -3 Sept. 1987. Vol. 3. A.A. Balkema, Rotterdam, The Netherlands. pp. 1087-1146.

Alonso, E.E., Gens, A., and Josa, A. 1990. A constitutive model for partially saturated soil. Géotechnique, 40(3): 423-439.

Alonso, E.E., Josa, A., and Gens, A. 1992. Modelling the behaviour of compacted soils upon wetting. In Rául J. Marsal Volume. Sociedad Mexicana de Mecanica de Suelos (SMMS), Mexico City, Mexico. pp. 207-223.

Alonso, E.E., Lloret, A., Gens, A., and Yang, D.Q. 1995. Experimental behaviour of highly expansive double-structure clay. In Unsaturated Soils: Proceedings of the 1st International Conference on Unsaturated Soils, Paris, 6-8 Sept. 1995. Vol. 1. Edited by E.E. Alonso and P. Delage. A.A. Balkema, Rotterdam, The Netherlands. pp. 11-16.

Barden, L., and Sides, G.R. 1970. Engineering behaviour and structure of compacted clay. Journal of the Soil Mechanics and Foundations Division, ASCE, 96(SM4): 33-51.

Barden, L., Madedor, A.O., and Sides, G.R. 1969. Volume change characteristics of unsaturated clay. Journal of the Soil Mechanics and Foundations Division, ASCE, 95(SM1): 33-51.

Cui, Y.J., and Delage, P. 1996. Yielding and plastic behaviour of an unsaturated compacted silt. Géotechnique, 46(2): 291-331.

Delage, P., and Graham, J. 1995. Mechanical behaviour of unsaturated soils: understanding the behaviour of unsaturated soils requires reliable concept models. In Unsaturated Soils: 
Proceedings of the 1st International Conference on Unsaturated Soils, Paris, 6-8 Sept. 1995. Vol. 3. Edited by E.E. Alonso and P. Delage. A.A. Balkema, Rotterdam, The Netherlands. pp. 1223-1256.

Delage, P., Audiguier, M., Cui, Y.-J., and Howat, M.D. 1996. Microstructure of a compacted silt. Canadian Geotechnical Journal, 33: 150-158.

Escario, V., and Juca, J.F.T. 1989. Strength and deformation of partly saturated soils. In Proceedings of the 12th International Conference on Soil Mechanics and Foundation Engineering, Rio de Janeiro, 13-18 Aug. 1989. Vol. 3. A.A. Balkema, Rotterdam, The Netherlands. pp. 43-46.

Fredlund, D.G. 1975. A diffused air volume indicator for unsaturated soils. Canadian Geotechnical Journal, 12: 531-539.

Fredlund, D.G., and Morgenstern, N.R. 1977. Stress state variables for unsaturated soils. Journal of the Geotechnical Engineering Division, ASCE, 15(3): 313-321.

Fredlund, D.G., and Rahardjo, H. 1993. Soil mechanics for unsaturated soils. John Wiley Publications, New York.

Gens, A. 1995. Constitutive modelling: application to compacted soils. In Unsaturated Soils: Proceedings of the 1st International Conference on Unsaturated Soils, Paris, 6-8 Sept. 1995. Vol. 3. Edited by E.E. Alonso and P. Delage. A.A. Balkema, Rotterdam, The Netherlands. pp. 1179-1200.

Hilf, J.W. 1956. An investigation of pore pressure in compacted cohesive soils. Technical Memorandum 654, Bureau of Reclamation, U.S. Department of the Interior, Denver, Colo.

Javadi, A.A., and Snee, C.P.M. 2001. The effect of air flow on the shear strength of soil in compressed-air tunnelling. Canadian Geotechnical Journal, 38: 1187-1200.

Jennings, J.E., and Burland, J.E. 1962. Limitation to the use of effective stress in partially saturated soils. Géotechnique, 12(2): $125-144$.

Lawton, E.C., Fragaszy, R.J., and Hardcastle, J.H. 1989. Collapse of compacted clayey sand. Journal of Geotechnical Engineering, ASCE, 115(9): 1252-1267.

Lawton, E.C., Fragaszy, R.J., and Hardcastle, J.H. 1991. Stress ratio effects on collapse of compacted clayey sand. Journal of the Geotechnical Engineering Division, ASCE, 117(5): 714-730.

Matyas, E.L., and Radhakrishna, H.S. 1968. Volume change characteristics of partially saturated soils. Géotechnique, 8(4): 432448.

Seed, H.B., and Chan, C.K. 1959. Structure and strength characteristics of compacted clays. Journal of the Soil Mechanics and Foundations Division, ASCE, 15(3): 313-321.

Sharma, R.S. 1998. Mechanical behaviour of unsaturated highly expansive clays. D.Phil. thesis, University of Oxford, Oxford, UK.

Sivakumar, V. 1993. A critical state framework for unsaturated soil. Ph.D. thesis, University of Sheffield, Sheffield, UK.

Sivakumar, V., and Wheeler, S.J. 2000. Influence of compaction procedure on the mechanical behaviour of unsaturated compacted clay, part 1. Géotechnique, 50(4): 359-368.

Smith, G.N., and Smith, I.G.N. 1998. Elements of soil mechanics. 7 th ed. Blackwell Science Inc., Oxford, UK.

Wheeler, S.J. 1988. The undrained shear strength of soils containing large gas bubbles. Géotechnique, 38(1): 399-413.

Wheeler, S.J., and Karube, D. 1995. State of the art report: constitutive modelling. In Unsaturated Soils: Proceedings of the 1st International Conference on Unsaturated Soils, Paris, 6-8 Sept. 1995. Vol. 3. Edited by E.E. Alonso and P. Delage. A.A. Balkema, Rotterdam, The Netherlands. pp. 1323-1356.

Wheeler, S.J., and Sivakumar, V. 1995. An elasto plastic critical state framework for unsaturated soil. Géotechnique, 45(1): 3553.

Zakaria, I. 1994. Yielding of unsaturated soil. Ph.D. thesis, University of Sheffield, Sheffield, UK. 